\title{
Edema in a Himalayan Toad, Duttaphrynus himalayanus (Günther 1864) (Anura: Bufonidae)
}

Krishnendu Banerjee, Deb Shankha Goswami, and Abhijit Das

Endangered Species Management Department, Wildlife Institute of India, Chandrabani, Dehradun, Uttarakhand, 248001, India (krishabd007@gmail.com)

U nlike a tumor, which is an abnormal growth of tissue resulting from excessive cell division, an edema is an externally visible disorder characterized by the subcutaneous or intracellular accumulation of fluid or bloating of the body from excessive gas production (Henle et al. 2017a). Edemas, frequently encountered in amphibian tadpoles, are less common in metamorphs (Henle et al. 2017a), although they have been observed in adult Ezo Brown Frogs (Rana pirica), Firebellied Toads (Bombina bombina), European Green Toads (Bufotes viridis), Common European Toads (Bufo bufo), Moor Frogs (Rana arvalis), Pacific Treefrogs (Pseudacris [= Hyliola $]$ regilla), and others (Henle et al. 2017b). Temperature shock, high light intensities, and experimental infestations of parasites such as trematodes (e.g., Ribeiroia ondatrae) and Blowfly (Lucilia bufonivora) maggots also are known to induce edemas in amphibians (Johnson et al. 2001; Kidov 2010; Henle et al. 2017b). In natural conditions, such deformities have been linked to chemical contamination, aberrations at the genetic level, radiation, nutritional deficiencies, and pathogens, such as viruses, bacteria, and fungal infections (Henle et al. 2017b).

At $0822 \mathrm{~h}$ on 13 October 2017, we encountered an adult Himalayan Toad (Duttaphrynus himalayanus) (SVL $81.6 \mathrm{~mm}$ ) in the Benog Wildlife Sanctuary, Mussoorie, Uttarakhand, India $\left(30.4685^{\circ} \mathrm{N}, 78.0231^{\circ} \mathrm{E}\right.$; WGS84; elev. $1,685 \mathrm{~m}$ asl $)$ with an edema emanating from its right flank and extending into the axilla and groin (Fig. 1). The edema was $39.2 \mathrm{~mm}$ in length, almost half of the snout-vent length of the toad. The specimen was collected, preserved, and deposited in the laboratory of the Wildlife Institute of India (WII/ADA-731), and a digital voucher was accessioned in the Lee Kong Chian Natural History Museum, National University of Singapore (ZRC[IMG] 1.188). The edema was confirmed by dissection; it was devoid of any tissue growth and contained only extracellular fluid. This toad also exhibited adactyly (congenital lack of digits), a type of ectrodactyly (partial or complete absence of one or all digits or shortening of the digits; Henle and Dubois
2017) on its right forelimb. This is the first report of such an edema in an anuran amphibian from India.

\section{Acknowledgements}

We thank the Uttarakhand Forest Department for permission to perform this study and the WII Grant in Aid project for

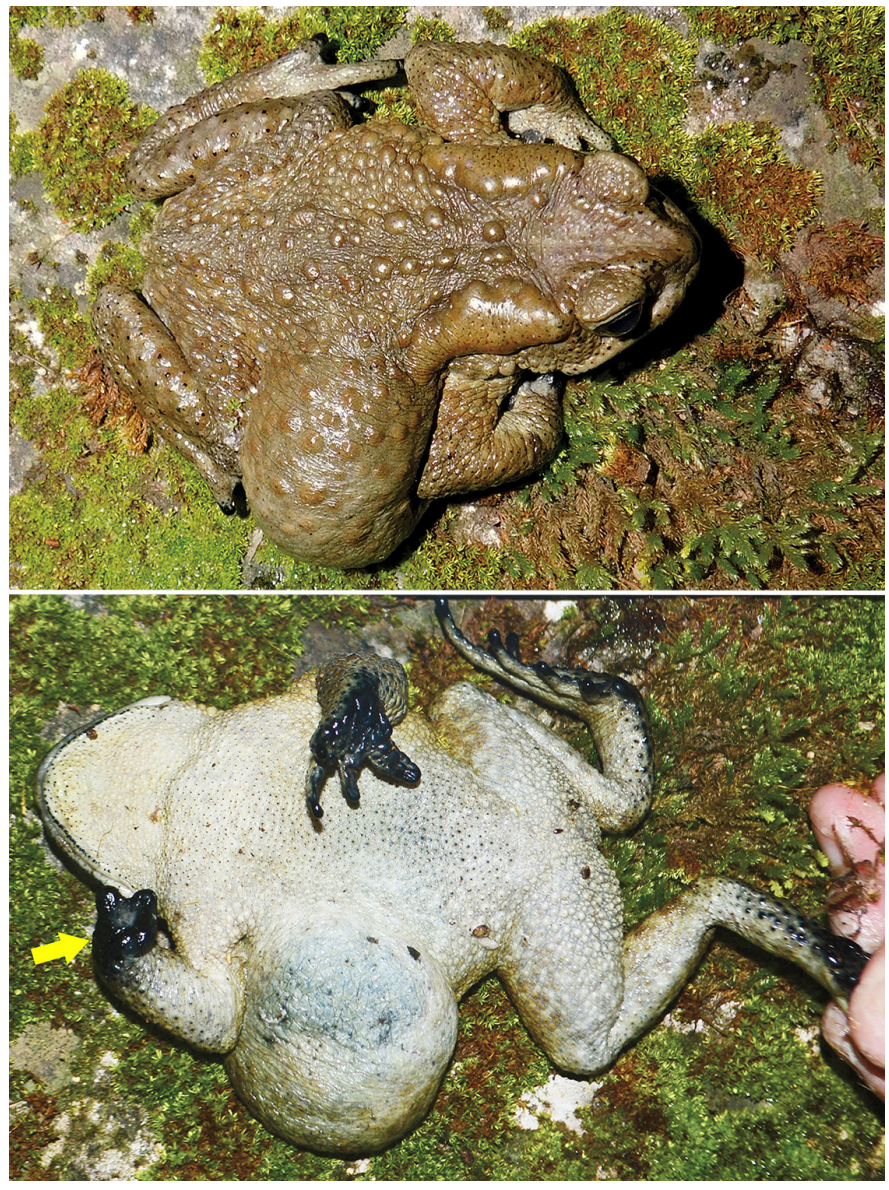

Fig. 1. Dorsal and ventral views of a Himalayan Toad (Duttaphrynus himalayanus) from the Benog Wildlife Sanctuary, Mussoorie, Uttarakhand, India, with an edema on its right flank. Adactyly or ectrodactyly on the right forelimb is indicated by an arrow. Photographs by Abhijit Das. 
financial support. Thanks to Chan Kin Onn, Natural History Museum, Singapore University, for providing the ZRC reference number and also Mr. Bitupan Boruah for help in making the photo plate.

\section{Literature Cited}

Henle, K. and A. Dubois. 2017. Studies on Anomalies in Natural Populations of Amphibians. Mertensiella 25: 8-255.

Henle, K., A. Dubois, and V. Vershinin. 2017a. A review of anomalies in natu- ral populations of amphibians and their potential causes. Mertensiella 25: 57-164.

Henle, K., A. Dubois, K. Rimpp, and V. Vershinin. 2017b. Mass anomalies in green toads (Bufotes viridis) at a quarry in Robwag, Germany: inbred hybrids, radioactivity or an unresolved case. Mertensiella 25: 185-242.

Johnson, P.T.J., K.B. Lunde, R.W. Haight, J. Bowerman, and A.R. Blaustein. 2001. Ribeiroia ondatrae (Trematoda: Digenea) infection induces severe limb malformations in western toads (Bufo boreas). Canadian Journal of Zoology 79: 370-379.

Kidov, A.A. 2010. Parasitism of larval Lucilia bufonivora on Bufo verrucosissimus. Estestvennye i Tekhnicheskie Nauki 3: 99-101. 